\title{
Party Political Panthers: Hegemonic Tamil Politics and the Dalit Challenge
}

\section{Hugo Gorringe}

\section{OpenEdition}

\section{Journals}

Electronic version

URL: http://journals.openedition.org/samaj/3224

DOI: $10.4000 /$ samaj.3224

ISSN: $1960-6060$

\section{Publisher}

Association pour la recherche sur l'Asie du Sud (ARAS)

\section{Electronic reference}

Hugo Gorringe, «Party Political Panthers: Hegemonic Tamil Politics and the Dalit Challenge », South Asia Multidisciplinary Academic Journal [Online], Free-Standing Articles, Online since 30 December 2011, connection on 21 December 2020. URL : http://journals.openedition.org/samaj/3224 ; DOI https://doi.org/10.4000/samaj.3224

This text was automatically generated on 21 December 2020.

\section{$\Theta \Theta \Theta$}

This work is licensed under a Creative Commons Attribution-NonCommercial-NoDerivatives 4.0 International License. 


\title{
Party Political Panthers: Hegemonic Tamil Politics and the Dalit Challenge
}

\author{
Hugo Gorringe
}

\section{Introduction: Hegemony and Dissent?}

1 We must both mould the movement according to the people and mobilise the people behind the movement. If the gap between these two widens too far the people will be alienated from the movement. ${ }^{1}$

2 The Dravida Kazhagam and Dravidian parties have fooled people for 50 years into thinking that the Brahmins are responsible for the caste system ... By pin-pointing this one enemy they have been able to cast all blame onto the Brahmins for their own gain). ${ }^{2}$

3 Across India and since the 1970s, movements amongst the lowest castes have begun to call themselves Dalits (literally, 'the oppressed') in a spirit of pride and militancy, and as a rejection of caste norms and values. ${ }^{3}$ Independent Dalit organisations mobilise for social justice and have won significant victories in social life and electoral competition. The ascension of R. K. Narayan to the Presidency of India, the election of Mayawati to the Chief Ministership of Uttar Pradesh, and the steady increase in the number of autonomous (that is not members of a mainstream party) Dalit Members of Parliament, of Legislative Assemblies and Panchayats, all suggest the erosion of the material and psychological structures that have underpinned institutionalised caste patronage in Indian politics. Given the history of non-Brahmin and Dravidian mobilisation in Tamil Nadu one would expect this process to be particularly entrenched here.

Certainly, the Liberation Panther Party (VCK, Viduthalai Ciruthaigal Katchi)-the largest Dalit movement in Tamil Nadu, South India-which is part of this wave of Dalit politics, has now gained recognition as a political player. Indeed in 1999, when they abandoned their decade-long poll boycott and entered electoral competition as part of a third-front, Dalit movements promised to breathe fresh air into the stultified world of Tamil politics. 
They were perceived as radical actors with the capacity to shake up political institutions and re-connect them to the masses (Gorringe 2005). In the decade since then, however, that initial optimism has gradually evaporated. Speaking in 2008, Muthukumar -a social activist and commentator-insisted that 'they are finished' and foresaw the demise of the Panthers within five years. ${ }^{4} \mathrm{~T}$. Edwin, a Christian Dalit, was similarly disappointed, noting that 'they change track with each political wind'.

5 Significantly, these comments do not reflect a massive downturn in the party's electoral fortunes. Indeed, the VCK is now an established political player and its leader was elected to the Lok Sabha (Indian Parliament) as an MP in 2009. Rather, the sense of anti-climax is born of the VCK's all too perfect integration into the political system. The Panthers have arguably become so 'domesticated' that they resemble the very institutions they set out to reform. Whilst there is disagreement about the extent of this and arguments about how much the Panthers can achieve within the mainstream, there are echoes here of a broader discussion on the outcomes of socio-political mobilisation.

In his classic book, The Strategy of Social Protest, Gamson (1990: 28-9) argues that social movements aim at two basic outcomes: acceptance as political players and the securing of new advantages for participants. On the basis of this assertion, he devises a fourfold categorization of movement outcomes: groups gaining full acceptance and many new advantages are seen as successful and are said to have attained a 'full response'; those that are fully accepted but secure no advantages are subject to 'co-optation'; where movements gain many advantages but no recognition they are described as being 'preempted'; and finally, those that gain neither acceptance nor advantages, 'collapse'. Although he is one of the foremost theorists of social movements, Gamson operates within a broader political process approach that privileges the workings of institutional politics and neglects socio-cultural discrimination. We can, though, take Gamson's measures of success as a useful (albeit imperfect) springboard for analysis since, whilst Tamil Dalit activists clearly reject the social hierarchies of caste through which daily life is mediated, the focus here is on the integration of Dalit parties into political institutions.

7 The starting point for these deliberations is the disparity between the VCK's successful pursuit of the politics of recognition and the pessimism of activists above. Pandian (1992) notes how the two dominant parties in Tamil politics have secured the active consent of subaltern classes despite neglecting their interests. At the least, the Dravidian parties have managed to secure Dalit votes until recently. The admixture of cinematic and material populism used to this end means that many of my Dalit respondents still spoke of M.G. Ramachandran (MGR), a famous star of the Tamil screen who founded one of the main Tamil parties and became Chief Minister of Tamil Nadu, as a heroic figure in the late 1990s. Karanth (2004: 162) argues that we need 'to identify the different forms of dissent and their limitations, for the ex-Untouchable castes in India today are seeking a form of patronage that does not reduce them to cultural dependence'. As Dalit parties have moved from campaigns against social injustice and begun to demand a 'share of political power' (a VCK slogan in 1999), they are seeking a form of recognition that does not reduce them to political redundancy.

8 The Viduthalai Ciruthaigal Katchi has successfully transformed from the largest Dalit movement in Tamil Nadu into a recognised political organisation. Despite the obvious political achievements of the party, activists and commentators express disappointment or disillusionment with its performance. The Panthers clearly reject the caste hierarchy, but they increasingly replicate hegemonic forms of politics which can undermine their 
aims. In exploring Dalit challenges to, and compromises with Dravidian hegemony, this paper contends that the frustrations expressed by activists and commentators largely stem from the disjunction between rhetoric and reality in Dalit politics. Whilst movements promise to eradicate caste and renew political institutions, Dalit parties become not only reconciled or resigned to democratic participation (Gundimeda 2009), but actively recreate the forms, structures and styles of politics from which they were previously excluded. ${ }^{6}$ This paper explores how Dalit parties situate themselves in relation to the hegemonic politics of the state.

9 We begin by considering the particularities of Tamil politics and examine the integration of Dalit parties and the impact that this integration has had. In so doing, we draw on Gamson's work on political recognition to chart the extent to which Dalit parties can be said to be successful in the state. Having outlined the contours of Dravidian politics, we trace the political trajectory of the VCK, charting its resistance to and compliance with Dravidian hegemony and argue that the path-dependent behaviour of the party partly explains this disjuncture between activist and political perceptions. We see how the dominant political parties have set the template for what it means to 'do' institutional politics in Tamil Nadu which serves as both an opportunity and a constraint for potential challengers. This template has determined the institutionalisation of agitational politics, both at the level of political practice and ideology. The paper, thus, shows how the VCK has been able to mobilise around Tamil nationalism whilst its anti-caste activities have been sidelined. This analysis of the political structures within which the VCK operates problematises Gamson's simplistic view of success and failure, by noting how even a 'full response' (acceptance and gains) may be seen as a form of co-optation by activists if it means that the party is constrained to operate within established parameters.

\section{Dravidian Politics in Tamil Nadu}

Understanding the complex and often contradictory articulations and practices of Tamil Dalit parties requires an appreciation of the politics of the state. Political participation and institutions in Tamil Nadu have been defined by 'a history of agitational politics' (Viswanathan 2004). The principal political parties in the state all emerged directly or indirectly from the non-Brahmin movement in the early $20^{\text {th }}$ century, particularly the organisations and mobilisational forms launched by E. V. Ramasami Naicker (popularly known as 'Periyar', 'the great one'). ${ }^{7}$ The most enduring of these organisations are the Dravida Kazhagam (DK, 'Dravidian Federation') and its two off-shoots, the Dravida Munnetra Kazhagam (DMK, 'Dravidian Progressive Federation') and All India Anna DMK (AIADMK). ${ }^{8}$ A detailed analysis of the non-Brahmin movement is beyond the scope of this paper, but it is clear that the progressive ideology and policies of Dravidian mobilisation rested on a middle-caste constituency that served to curtail and shape the politics of these parties in office (Subramanian 1999, Harriss 2002).

11 Tamil political institutions have been dominated by Dravidian parties since the 1967 election, but their influence was felt long before they assumed office. Successful mobilisation during the 1930s and 1940s placed caste categories and linguistic nationalism at the centre of Tamil politics meaning that Independence was portrayed as the replacement of one elite (British) by another (upper-caste, Hindi speaking Northerners). The DK was never a serious political contender and the Congress Party dominated institutional politics after Independence but saw their vote-share eroded at 
each election by the DMK. The DMK was a regional nationalist party which played on language nationalism (rather than insisting upon it) and espoused populist/socialist policies that were successfully mediated to the electorate through the means of cinema and an effective party organisation. In 1967, Tamil Nadu was the first Indian state to elect such a party to government.

Under its founder, Annadurai, and his successor, Karunanidhi, the DMK governed until 1976. Its political pragmatism, however, saw the party increasingly relinquish its radicalism both in terms of anti-Hindi agitation and economic policies. In 1972 in response to DMK 'corruption', MGR formed the AIADMK which wrested power from the DMK in 1977 due to MGR's popularity and populism (as typified by the free school meal for children). Since then, the two parties have alternated in power. Recent elections, however, suggest that the Dravidian parties are facing tougher challenges and struggling to gain clear majorities (Harriss 2002, Subramanian 2002, Wyatt 2002, Pandian 2006). The oscillation between the parties continues into the present, but the conflict between the two has never really been based on ideological or policy differences and both parties have toned down their linguistic nationalism and reigned in their social reform agendas. It is telling that MGR split away from the DMK over allegations of corruption rather than because he had a different vision. Both parties continue to offer similar, populist manifestos and elections continue to be fought on questions of corruption, abuse of power and dynastic succession.

The rise of coalition politics has been hailed in this context as potentially infusing new life and ideas into Tamil politics (Wyatt 2002). It clearly offers opportunities for emerging political actors (Gundimeda 2009), but it is important to bear two things in mind. Firstly, despite challenges to Dravidian politics, Dravidianism plays a hegemonic role in Tamil society and shapes the politico-cultural sensibilities of Tamils (Subramanian 2005: 3821). The Dravidian historical cultural narrative hinges on regionalism and 'pure Tamil' ( centamil), and is buttressed by the veneration of political leaders and film stars (George 2002, Bate 2009). As Bate (2009: 37) argues, Dravidian hegemony has 'served to protect the position of (non-Brahmin) privileged castes and classes'. Secondly, and most important for this paper, Dravidian rule has shaped what it means to 'do politics' in the state and this legacy may endure beyond any electoral reversals. In other words, irrespective of the policies and electoral performance of Dravidian parties, they established a political template that has both framed and influenced subsequent mobilisation. It is to an analysis of this template that we now turn.

\section{How to 'do' Tamil Politics}

Political organisations do not emerge or operate in a vacuum and comprehending the forms of contemporary Dalit institutions must, therefore, examine the existing 'rules of the game'. Dravidian parties, I contend, have significantly shaped the political culture of the state and influence the modes of mobilisation, political styles and approaches to caste and social radicalism that emerging parties adopt. In Tilly's (1986) terms, this 'repertoire of contention' serves both as an opportunity-in that it offers new entrants to Tamil politics a model and legitimising narrative to draw on-and as a constraint- in that deviations from the norm invite repression.

Subramanian (2002: 126) argues that Dravidian parties 'increased political participation, aided the representation of the emergent strata, enriched civic life, and thus 
strengthened pluralist democracy'. Social pluralism, he explains, refers to the proliferation of autonomous associational forms that are tied neither to the state nor to each other. This being the case, we would expect emerging groups to have little difficulty in organising or expressing themselves, and the burgeoning of political parties in the state over the past few decades would appear to confirm his argument. The primary path to political contestation in Tamil Nadu, however, is through mass mobilisation and agitation prior to political recognition (Harriss 2002, Gorringe 2005).

Successive parties that emerged from the AIADMK, the Vanniyar dominated Paatali Makkal Katchi ('Toiler's Party'), the Dalit Puthiya Tamizhagam ('New Tamilnadu') and VCK, however, have all resorted to (often extra-legal) protests to gain political recognition. Road and rail blockades, hunger fasts, the stoning of government buses and other forms of violence have become essential components of the Tamil activists' tool-kit. Dalit activists, thus, insisted that 'without protest we cannot achieve anything. One cannot claim anything from the government without protest. Only if we protest is there an opportunity for our community to do anything. ${ }^{9}$

It is not just the modes of mobilisation which reflect dominant norms. Emergent parties have tended to replicate the political styles of their predecessors too. Subramanian (1999) has rightly characterised Dravidian parties as populist political organisations that revolve around a central leader or 'big man' (Mines 1994) in whom power is centralised. Such leadership, as Price (1989) noted, derives from kingly models and establishes a hierarchical relationship between a leader and their followers. Bate (2009), however, demonstrates that the monarchical style of Dravidian politics was as much invented as inherited. The ties between Tamil cinema and politics are no coincidence here, and Pandian (1992) shows how politicians have used their screen image to attract voters and emphasise the importance of honour (mânam) in Tamil life, reinforcing and reinterpreting cultural values in the process.

Subramanian $(1999,2002)$ contends that the emphasis on a central leader is mitigated by significant 'cadre autonomy' and he observes how schisms result in the formation of new parties to support this claim. Splits, however, tend to occur when there is a disgruntled rival for the throne rather than a popular uprising. The most successful such schism culminated in the formation of the AIADMK by MGR. Subsequent attempts to emulate this model, notably by V. Gopalsamy ('Vaiko'), have failed to create viable alternatives to the two main political parties. Chandhoke (1999), furthermore, points to deep-rooted power asymmetries which lead to cadre prostrating themselves before their leaders. Dalit activists rarely went to such extremes but their behaviour and political structures indicated that they shared the perception of leaders as heroes or semi-deities (Bate 2009, Wyatt 2010). Leaders were deferred to, asked to name children and bless marriages and their speeches and likenesses were treasured. When Thirumavalavan (the VCK leader) was ill, much of the social and political life of the VCK party came to a standstill (Gorringe 2005). This partly reflected the esteem in which he was held, partly indicated the lack of an established secondary leadership, but partly mirrored a wider socio-political structure in which leaders are venerated (George 2002: 518). Opponents, potential followers, the media and existing cadre create certain expectations and rituals of leadership. The celebration of lyrical Tamil rhetoric and the need to reach out to a semi-literate constituency in the case of Dalit leaders combine to mould the institution of leadership. De Wit's (1996: 65) detailed study of political intermediaries in Tamil Nadu, thus, points towards a 'politics of mass idolatry' which renders people dependent on the state or, at 
least, on brokers who mediate between them and the state. The pre-eminent position of party leaders was bolstered by structures that placed them at the centre, but was further reinforced by caste considerations (Gorringe 2010).

19 At first sight, it is a paradox 'that such a large number of caste parties should sprout in Tamil Nadu, the cradle of the Dravidian movement' (Subramanian 2001: 46). It is paradoxical because Periyar is hailed as an inspiration by all Tamil leaders. The Dravidian movement was, rhetorically at least, committed to the struggle against caste discrimination and sought to foster a Tamil identity that subsumed other social faultlines. There is a smug complacency in the utterances of Tamil politicians each time the issue of reservations flares up, and they are proud of Tamil Nadu's history of positive discrimination to tackle inequalities. ${ }^{10}$

In what sense, then, is the tendency for caste-based parties a legacy of Dravidianism? Harriss (2002) maintains that the growth of caste-based parties reflects a betrayal of Dravidian discourse, whilst Subramanian (2002) views their emergence as reflecting the gradual decline of the Dravidian parties. Prior to this, he argues, 'Congress, the DMK and the AIADMK absorbed most caste groups into their social coalitions' (Subramanian 2002: 133). Whilst this is undoubtedly the case and both positions have some justification (and are not necessarily incompatible), they avoid the question of why caste remains such a salient form of identity despite nearly a century of non-Brahmin mobilisation.

21 The 'frustrations of the ambitions of individual politicians' (Harriss 2002: 109) certainly play a part, and social movement research points to mobilisation as a vehicle for political advancement (Tarrow 1998, McCarthy \& Zald 1987). This still begs the question of why caste was so readily available to leaders after the long history of Dravidian agitation and rule. Following Barnett (1976) I argue that one reason for this is that caste was placed at the centre of Dravidian deliberations and practice. Though Periyar supposedly 'fought both the caste system and Brahmin hegemony' (Subramanian 2001: 46), Dravidian organisations were built around the dominant middle-castes (Barnett 1976, Ravikumar 2006) and the architecture of caste-based reservations in Tamil Nadu extended the benefits secured for SCs to those categorised as Sudra castes at an early stage. Subramanian's (1999) own work demonstrates the degree to which Dravidian parties were dominated by $\mathrm{BC}$ groups and interests.

22 From the outset, thus, caste was built into Tamil politics even as it was spoken out of it (Pandian 2008). Non-Brahmin is an apt nomenclature for a movement that displaced one elite group with another. The lack of a coherent anti-caste programme is seen in the failure to carry through land-reforms; the continued exclusion of Dalits; economic dominance of Brahmins; the failure to extend reservations to the most marginalised castes until forced to do so by mobilisations; and the normalisation of Hindu nationalism (Harriss 2002, Rajadurai \& Geetha 2002, Ravikumar 2006). As 'Tada' Periyasami's quote at the head of this paper emphasizes, the Dravidian parties have been adept at constructing Brahmins as the common enemy for their own gain. ${ }^{11}$ As Barnett (1976: 318) argues, the DMK presented itself as championing the 'common man' but particularly appealed to 'the Backward Castes'.

23 Clearly, Dravidian social radicalism was strictly curtailed. Rather than envisaging inequality in class or caste terms, the Dravidian parties employed the Brahmin/NonBrahmin divide to suggest a commitment to social change even as its leadership and core constituency was drawn from dominant, landowning Backward Castes (Barnett 1976, Subramanian 1999, Harriss 2002, Ravikumar 2006). By stressing language rather than 
class, the DMK (and later the AIADMK) attempted to create an imagined community of Tamils and avoid acting upon its politically sensitive election pledges on land-reform, dowry and caste. Barnett (1976: 93) notes how the DMK consciously toned down its radical reform agenda in the late 1950s to improve its electoral chances against Congress. In portraying Congress as a national party divorced from the concerns of Tamil voters, the DMK narrowed the political field to the terrain of cultural nationalism (Barnett 1976, Wyatt 2010). Social radicalism gave way to a populism that gave the impression of social justice whilst leaving underlying structures intact (Pandian 1992, Harriss 2002). It is precisely because the core constituency and political priorities of the Dravidian movement were so exclusive-neglecting the interests of marginalised groups-that caste has become so salient in contemporary politics.

This brings us neatly to a final legacy of Dravidianism: the perennial tension between radical, populist rhetoric and a politics of pragmatism. The political culture that values heroism, demagogues and film-script endings places an emphasis on lyrical speechmaking, a commitment to the poor and needy and the defence of ones' honour and social standing (Pandian 1992). The result is a brand of populist politics that subsumes 'politics in rhetoric, concrete concerns in symbolic ones' (Rajadurai \& Geetha 2002: 119). The lofty rhetoric of the hero or firebrand founders on the rocks of structural inequality and social inertia.

Political institutions, Rob Jenkins (1999: 224) argues, are 'the means by which democracy's change-resistant tendencies are overcome'. When those institutions are constituted by and for particular social categories, however, they can also be the means by which calls for change are diluted. Where the Bahujan Samaj Party (People's Majority Party) in Uttar Pradesh has been able to field Dalit politicians and win power in the state (Chandra 2004), the bi-polar nature of Tamil politics has precluded minorities from gaining power (Gorringe 2007). Even in Uttar Pradesh, as Jaoul (2007: 142) shows, political power is 'regarded as a potential trap for an authentic people's movement', with the result that an array of 'non-political' organisations have emerged to advance the concerns of the grassroots activists. That the Dravidian parties repeatedly secure the votes of marginal groups could suggest that they represent the interests of diverse groups, but marginal groups have increasingly challenged Dravidian hegemony noting its failure to properly represent differing constituencies. An emphasis on caste, however, has militated against the formation of a united opposition. ${ }^{12}$

The lack of a viable third front testifies to the Dravidian parties' ability to construct an overarching sense of Tamil-ness but also reflects the inability of established institutions such as the Congress or the Communists to come to terms with contemporary expressions and anxieties. Neither of these organisations has either had a popular, demagogic leader or been comfortable aligning themselves with caste-based parties partly because an alliance with one of the two Dravidian parties is seen as essential to gain power. These concerns have infused the strategies of emergent outfits too, with no recognised political players prepared to go it alone until the Desiya Morpokku Dravida Kazhagam (DMDK, National Progressive Dravidian Federation) in 2006. Thirumavalavan, the VCK leader who called Karunanidhi a scoundrel and Jayalalitha [the leader of the AIADMK which was in opposition at the time] a rogue, thus, according to Muthukumar now deploys more honorific titles for his potential allies. ${ }^{13}$ 


\section{From Cheris to Chennai?}

In its passage from an outsider to a recognised party, the VCK has followed a well-trodden path to political assimilation. During the poll boycott that denied the legitimacy of political institutions, the party declared that 'none of you are honest, so none shall have our votes' as put by Thirumavalavan. ${ }^{14}$ In keeping with this, their first foray into politics was a part of a third front that consolidated Dalit interests in alliance with the state wing of the Congress Party (Wyatt 2002, Gorringe 2005). That front emphasised the necessity of articulating and building alternatives, but within months of the elections in 1999 the VCK was allied to the AIADMK. Since then, it has switched sides with little consistency (sometimes refusing to be allied to the Hindu right, at others rejecting any coalition with the PMK) (Gorringe 2007).

For Roberts (2010), the VCK has succeeded in stripping Dalit voters away from the Dravidian parties through its electoral engagement and espousal of Tamil nationalist rhetoric. Wyatt (2010: 132) concludes that it has 'helped to change the dynamics of the party system'. He also acknowledges that the nascent shift towards multipartism in Tamil politics is bi-polar in nature, but his analysis suggests that the emergent parties have significant scope for manoeuvre. By contrast, I contend that political 'replication' by the VCK means that Dalit parties are not simply reconciled to the legitimacy of electoral contestation but to hegemonic modes of doing politics as well. I should stress here that I do not see this as 'replicating caste-based relations in the political arena' (Gundimeda 2009: 57). The argument is about political rather than social forms of engagement. Thus, those parties that have opted not to follow the time-worn path to political representation have failed to gain electoral successes. Puthiya Tamizhagam (New Tamil Nadu) was thoroughly marginalized for a decade after 1999, due to its attempts to go it alone (Wyatt 2010), but was politically resurrected (in the words of a CPI(M) activist) in 2011 thanks to its alliance with the AIADMK. Other minor political players like the PMK have also failed to go it alone. Significantly, however, hegemonic politics does not simply mean allying with one or other of the main parties; it also shapes how those parties are organized and operate. In major respects they seem to offer a mirror-image of the parties they set out to displace. The VCK, thus, is structured around Thirumavalavan and mainly appeals to a Paraiyar constituency. ${ }^{15}$ The ambiguity of the VCK's position is exemplified by the use of the terms 'Dalit' or 'Liberation Panther' that do not refer to any individual caste group in particular, even as orators reify their 'Paraiyar Ambedkar'. VCK activists liked to boast that they had an established secondary leadership and pointed to the committee of representatives that decided whether to contest elections in 1999. Thirumavalavan, however, remains the epicentre of the party. Indeed, when I sought to capture his speeches on camera at a flag-raising ceremony, one of the District coordinators of the movement enjoined me to 'take some photos of us not just of MGR'. ${ }^{16}$ This accusation has become more barbed since Thirumavalavan inverted the usual connection between cinema and politics by starring in films having made his name as a politician.

The VCK, like its Dravidian predecessors, emphasised that it fosters cadre autonomy. 'The VCK was built up with one pager', Thirumavalavan insisted, 'I cannot be everywhere at once'. ${ }^{17}$ The leader, however, was ever-present, even when physically absent, as an image, an oracle whose speeches and interviews were (re)cited approvingly, and as an arbitrator tasked with deciding between courses of action. Like other parties, therefore, the VCK 
faces problems of succession and schism: 'Tada' Periyasami, one of Thirumavalavan's trusted deputies, left to form his own movement in 2002, and one of the two MLAs elected in 2006, K. Selvam, cited concerns about over-centralisation in 2008 (Kolappan 2008). There were no institutional mechanisms for a transfer of power or the election of a successor. Clearly this is an issue that affects all political parties in Tamil Nadu. Bate's book (2009) on Dravidian politics captures the way in which party cadres engage in forms of public devotion towards their leaders and points towards the importance of financial centralisation. Whilst one might expect challenging groups seeking to democratise Tamil politics to be more democratic, this is clearly not the case. It is not that alternate models of leadership are absent since women's wings, women's rights movements and the Tamil Dalit Liberation Movement have all sought to prefigure a more egalitarian structure. Rather, the prevailing political culture exerts a powerful constraining force by creating particular expectations and institutions.

The expectation that the party will revolve around a 'big man' shapes the VCK's political performances. ${ }^{18}$ Flag-raising ceremonies (that mark an organisation's presence in a locality), for instance, could be structured as community celebrations but revolve around the visit of the leader. Activists and well-wishers desire the attention of Thirumavalavan and view him as a heroic figure in the struggle against caste injustices. Demonstrations and rallies are designed to give prominence to the key figure and media outlets, police and opposition parties all seek access to an authoritative spokesperson. Furthermore, whilst the electoral successes of the party might have been expected to result in the formalization of organizational roles and responsibilities, Sridharan (2001) notes how the cost of elections and the discretionary expenditures offered to MPs both result in the centralization of party purse strings. I could confirm this point during my fieldwork in 2010: walls and billboards in Chennai and Madurai were daubed in the colours and slogans of the VCK. As one political commentator noted, however, the increase in wall space was in inverse proportion to the number of volunteers prepared to wield a brush. ${ }^{19}$ The increase in resources had been matched by rising demand for payment. Prominence, thus, comes at a price. As well being under increased financial pressure, the VCK was said by respondents in 2010 to have been drawn into corruption and racketeering. The VCK, in other words, has joined the Dravidian parties and 'partaken of the larger process of rentseeking, using resources thus gained to disburse patronage' (Economic and Political Weekly 2010: 9).

31 The way the political system is structured, thus, tends to generate certain forms and modalities of political expression. Similar constraints conspire to channel Dalit movements towards caste categories or Tamil nationalism. Chandra's (2004) work on 'ethnic head-counts' suggests that people vote for someone from their own community to secure the benefits of office. This rational actor model fails to resonate in Tamil Nadu where Dalit parties rarely gain office and neglects the more impassioned aspects of caste communities. People mobilise around caste for more than purely instrumental reasons. They do so in response to the fictive kinship that caste categories establish; the community-making work undertaken by movements and parties; the repression they face as a group and the powerful appeal of caste pride. Successive challenging groups have used, as Pandian (2000) attests, the emotive language of caste pride to generate a following and to foreground the issues of discrimination and exclusion. The powerful sentiments aroused by such strategies are evident in the assertions of activists like Anandan Paraiyar: 
Many acquaintances were cut off after people discovered my caste - so why not say it openly? Some people tell me they don't like my calling myself 'Paraiyar', but it is to identify myself ... those on the floor have to rise up and realise that they are being enslaved. Why should we live in fear of this society? Why not be open? ${ }^{20}$

The quote is typical in pointing to continuing oppression as a rationale for retaining a focus on caste. Across Tamil Nadu, Dalit and intermediate groups unite around caste to demand recognition. VCK cadres, thus, are almost invariably Dalit and mostly hail from the Paraiyar caste category. Whilst there is a core of urban, educated, middle class activists, the bulk of the movement is made up from urban estates or squatter settlements and rural villages where people feel that the party might lend them some security (Gorringe 2005). This logic is self-perpetuating as an emphasis on caste can polarise communities and exaggerate tensions, thus rendering mobilisation on the basis of caste more attractive, if not imperative.

4 The alternate identity with social cache is that of Tamil nationalism. Given how the project of Tamil nationalism has been tied-up with the interests of intermediate castes from the outset this would seem to be a counter-productive strategy. 'Tada' Periyasami thus insisted that 'Tamilians were oppressed by Tamilians before the Brahmins came along'. ${ }^{21}$ Acting on this belief, however, is hampered by the deep-rooted attachment to Tamil-ness in the state and by Thirumavalavan's commitment to the Sri Lankan Tamil cause (which featured heavily in the party's 2011 manifesto). Dalit movements here, thus, have invariably oriented themselves towards nationalist discourses and the VCK seeks a 'nation of Tamils free from caste exploitation'. As the party became more mainstream it emphasised its Tamil credentials by vociferously supporting the cause of Tamil Sri Lankans.

\section{Institutionalising the Dalit Challenge?}

5 The VCK thus mirrors the hegemonic organisational structures, priorities and discourses of the institutions from which it was excluded. Its assimilation into Tamil political culture has occasioned frustration, depression and anger amongst some cadre who view the party as having succumbed to 'suitcase politics'; the contemptuous phrase implying corruption (or suitcases full of cash). Allegations abound surrounding the VCK's links to established parties and, according to numerous respondents in 2010, big business, real-estate and racketeering. Irrespective of the veracity of these claims, the conviction that they are tainted for some activists and the perception that they are tainted more widely, confirms the concerns voiced by a VCK activist in 1999 about coalition politics:

Now what happens when we give support is that they make us sacrificial lambs. For us, there are no benefits or rewards from the process at all. When allying to the DMK or AIADMK or Congress and joining a coalition, we have to go and vote for them. Even if we work for them, 'no benefit' [in English]. We cannot do anything for our community-not for me-for our community. Protesting as a party will not gain what this community needs. ${ }^{22}$

Subramaniam suggests that political participation is stacked against Dalits and cannot benefit them. He goes on to argue that if the calf joins the piglets then the two become one and you cannot distinguish between them' and concludes: 'don't go to any political party, don't vote for them, they will neutralise you'. Political engagement is cast as 
unrewarding and is seen to emasculate movements and draw their sting. Radical movements, as Dalit activist and NGO worker R. Manohar argued, get 'sucked into state or national politics' and get assigned petty administrative roles and responsibilities that result in them becoming 'mired in the petty politics of bureaucracy.'. ${ }^{23}$ So, has political engagement domesticated the Liberation Panthers? Have they, in Gamson's terms (1990), been co-opted?

This question is posed to most social movements that enter the political mainstream (Offe 1990). Coy and Hedeen (2005: 407) similarly argue that institutionalisation may lead a movement to become 'bureaucratized and technique-centred, losing its adaptive vitality'. They note that institutional assimilation can involve a dilution of movement critiques and tactics. The strategies that mobilise activists are rarely transferable to the broader constituencies targeted in election campaigns (Offe 1990, Della Porta \& Diani 1999), and some compromises are inevitable in the attempt to widen appeal. In this context, replicating the discourses and strategies of opponents is appealing not least because it projects their protest as the continuation of 'past political movements whose struggles have long since been vindicated as just' (Della Porta \& Diani 1999: 184).

What we see in the Tamil case, however, illustrates a further and more pervasive dimension to such processes. Whilst the above accounts focus on political institutions and the mechanisms by which challengers are integrated and their actions routinised, the example of the VCK emphasizes the socio-cultural relationships that animate the political sphere. It is not just that the party's platform has been blunted by the formalized nature of its political participation, but that its mode of operation, style of protest and political rationale have all been recalibrated in the process. In his book on Tamil oratory, Bate elucidates the socio-cultural significance of the distinction between pure or refined ( cenmai) and vulgar (kochai) Tamil (Bate 2009: 5-6). This distinction maps onto a blueprint for political performance in which the former is perceived and portrayed as the 'proper' way of doing politics. Leaders are valorised for their ability to deliver lyrical speeches in pure Tamil (Bate 2009, Gorringe 2010). Drawing on Bourdieu, Bate notes how this hierarchical schema assumes a doxic quality that naturalises particular social institutions that are, in fact, the products of certain status groups. He further argues that these 'judgements about language often correspond to judgements about entire classes of people' (Bate 2009: 9).

Bate does not elaborate on this process, but it encapsulates the paradox of institutionalisation for Dalit Parties in a Tamil context. In adhering to the taken-forgranted Dravidian aesthetic and adopting the refined modes of political engagement, the VCK unwittingly reinforces a hierarchy that casts Dalits as lesser beings. Given that most Dalits communicate in kochai (vulgar) Tamil language and practice folk arts and games that are perceived as being pre-modern (Ravikumar 2009), the institutionalisation of a grassroots Dalit movement can serve to sever the links between leaders and led. Chatterjee (2004: 64) argues that a 'viable and persuasive politics of the governed' requires 'a considerable act of mediation'. Whilst the VCK's entry into politics suggested that it could fulfil the role of mediator (Gorringe 2005), its assimilation into hegemonic modes of doing politics has increasingly rendered the party unable to mediate. In this, its institutionalisation echoes that of the BSP in Uttar Pradesh which, as Pai (2002) show, came to be seen as an anti-Dalit party. Pai notes how Dalits came to rely on alternate forms of collective mobilization for protection against caste atrocities. Jaffrelot (2003: 294) portrays the incremental transfer of power to lower castes in India as a 'silent 
revolution', but notes that mobilisation from below may 'not be able to dislodge the elite for several decades'. In the Tamil context, more than in UP, the bipolar nature of elections and the forms of populism espoused by the two main parties means that the elite are not only entrenched but are able to cast themselves as the champions of the poor. When Dalit parties ally with each Dravidian party in turn in this context, they reinforce these claims. The upshot, as an activist and academic, puts it, is that 'Dalit Parties are doing very well, but Dalit liberation is not. The structure remains intact'. ${ }^{24}$ In a context where the aim of the movement was to redress social inequalities, political recognition within existing structures has served to buttress the very institutions the VCK set out to contest.

Recognising this as a potential problem, Thirumavalavan took pains to insist that "we must be with the people ${ }^{\prime 25}$ and that mobilisation must ensure the continuity of the party in his absence. This conviction, however, has not been communicated to cadres who continue to defer to the leader rather than act on their own initiative. The limited autonomy of grass-roots campaigners was underscored in 2006 when dedicated local activists were not nominated for electoral candidates and more favoured representatives were parachuted in (The Hindu 2006). And it was tragically underscored in 2009 when two VCK affiliated youths responded to Thirumavalavan's hunger-fast for Sri Lankan Tamils by committing or attempting suicide (The Hindu 2009a, The Hindu 2009b). Whilst the adoption of Tamil nationalism during the Sri Lankan war may have been politically astute, it begs the question of what the party stands for. As Chezhian, a long-term VCK activist and supporter, put it: 'Now if you ask a member of the party what their demands are, they should be able to tell you shouldn't they? But it is unclear whether it is Sri Lanka, Tamil Nationalism or Dalit rights'. ${ }^{26}$

The gap between activists and leadership was best illustrated, though, in the activities of the women's wing. Though they were celebrated and called on in times of need, there was little recognition of female leaders or demands (Gorringe 2005: chapter 6). The limited recognition accorded to grassroots women leaders such as Pandiyammal, has also been tempered by the patriarchal emphasis of the Tamil Protection Movement launched by the VCK and PMK (see below). There were frequent assertions that organisation, consciousness raising and mobilisation were central to the VCK as a movement, and the 1999 election campaign certainly energised people who had never voted before. The recurrent insistence from leaders and activists was that 'we can't sort things out for you, you need to take steps first'. ${ }^{27}$ Flag-raising ceremonies were preceded by local organisation and consciousness-raising, therefore, and offered secondary leaders the chance to speak. The party, however, falls into the 'image trap' (Pandian 1992), and could do more to promote local figures and bridge the gap between these leaders and the grassroots. ${ }^{28}$ Their efforts are constrained, however, because institutional structures encourage centralised parties and also due to a popular demand for heroic leaders or champions. Most of those interviewed about VCK activism, for instance, cited their attachment to, and reverence towards, the leader who was cast as a deliverer or champion (Gorringe 2005). Similarly in 2010, even those who were critical of the party and Thirumavalavan's focus on Sri Lanka still regarded him as their leader.

The focus around a pre-eminent 'big man' is not accidental. Price (1999) describes durable cultural patterns of kingship which map onto patron-client relations in the present day. Contemporary patronage, however, derives as much from Dravidian models of politics (Bate 2009) and party finances (Sridharan 2001) and does not necessarily tessellate with 
caste. Dalit beneficiaries, thus, may be dependent on, or indebted to, upper-caste patrons and the emergence of Dalit MPs has further complicated patterns of patronage. It is telling in this context, that the most successful recent attempt to emulate the broader appeal of the Dravidian parties has seen Vijayakanth of the DMDK consciously embrace 'the style of politics that has been practiced in Tamil Nadu since the 1970s' (Wyatt 2010: 167). Vijayakanth gained prominence as a screen idol, but his success, as Wyatt (2010:170) notes, is down more to the way in which he has managed his fan-clubs and image such that it meshes with 'established structures of meaning' and ways of performing politics for the media, allies and opponents and constituents in contemporary Tamil Nadu.

The terrain occupied by Dalit politics, however, extends beyond the institutions of formal politics into the socio-political structures of caste. Since the Dravidian parties have colonised the centre-ground and masked their caste composition in (sub)nationalist terminology, successive challengers have resorted to caste as a means of mobilising followers and gaining legitimacy. Caste constituencies are said to be easier to mobilise, in part due to the rational self-interested 'head-count' politics described by Chandra (2004) and in part since caste politics serve to animate caste identities and make them meaningful to people on the ground. The VCK, thus, established itself through castebased conflicts with the Vanniyar PMK and is entrenched in areas where Paraiyars are most populous (Arun 2007). Whilst VCK speeches typically reached out to religious minorities and condemned abuses against Dalits (Gorringe 2010), therefore, it remains a predominantly Paraiyar party and has failed to reach out and build on its political success. The twin structures of political leadership and caste constituencies have eroded attempts to forge pan-Dalit unity in the state. In the absence of a coherent anti-caste Front, however, Dalit activism is curtailed.

Not only do existing political repertoires render Dalit parties subservient to their larger allies, Dravidian hegemony has succeeded in focusing attention on the political aspects of caste at the expense of the social relationships that uphold it. Campaigns for inter-caste or self-respect marriages; a willingness to share platforms with other Dalit leaders and the forging of links with unions and peasant groups would have been consistent with an anticaste agenda. Instead, the VCK joined forces with its erstwhile opponent the PMK in the Tamil Protection Front which set itself up as defending the honour of the Tamil language and Tamil women. Thirumavalavan (2003: 60) elsewhere argued that "chastity is only a violence fabricated by men-for the benefit of men-and imposed on women. Tamil society's code of life has been ordered only central to that'. The TPM's vociferous campaign against the actress Kushboo, for daring to suggest that sex before marriage occurred in Tamil Nadu, however, obscured the centrality of chastity, arranged marriages and monogamy to the reproduction of caste (George 2002: 502).

The TPM was an attempt to escape caste confines through Tamil nationalism. The espousal of linguistic nationalism, however, is fraught with contradictions even where it is tempered by respect for other languages and an emphasis on caste eradication (Roberts 2010). Most Dalits speak in devalued and derided dialects and marginalised Dalit castes speak Telegu at home. More insidiously, the national card tends to trump all others. Though Thirumavalavan employs Tamil identity to signify a community of Tamilians free from caste and untouchability, thus, his stance on the Sri Lankan conflict reveals the perils of this position. To the question 'What is the stand of [the VCK] in the recent ongoing Sri Lankan peace talks?', Thirumavalavan answered: 
47 As Tamils, it is our duty to join together in solidarity towards this peace process. The participation and involvement of Dalit Movements can be decided only after a significant peace atmosphere is established here (Anbuselvam 2002: 1, emphasis added).

Despite work by Ravikumar (2002) and others which reveals the Liberation Tiger's complete neglect of the Dalit question, the VCK under Thirumavalavan explicitly endorses the LTTE and implicitly prioritises the national over the caste struggle as was seen in his 2009 'fast-unto-death' on the Sri Lankan issue. Whilst the plight of Tamils caught up in the civil war demanded attention, the VCK response smacked of populism. Paraphrasing Ambedkar's response to Gandhi I might say; 'it would have been justifiable, if Mr Thirumavalavan had resorted to this extreme step for obtaining justice for the Dalits on which he has long insisted'. Indeed, when I suggested that Sri Lanka was an important issue, Chezhian argued: 'What is it to us? We are suffering and struggling daily and need our own champion'. ${ }^{29}$

\section{Liberation Panthers or Political Animals?}

Harriss' book (2006: 236) on institutions, politics and society in India notes that Tamil Nadu has relatively high-rates of pro-poor expenditure, in large part due to the high rates of political participation amongst the lower castes and classes. He, however, calls for more analysis of party politics focused on organisation, ideology, leadership and alliances. The significance of such research is underscored by Mosse's contention (2007: 22) that contemporary upper class/caste dominance rests more on their ability to act as brokers - mediating between the state and private individuals and corporations-than on more traditional land-based forms of patronage and dependence. In Subramanian's terms (1999: 69), older patronage networks have been superseded by forms of 'populist clientelism' which 'channels patronage through the extensive social networks of party subcultures, both to supporters and to others from the intermediate and lower strata whose support it hopes to attract'. Subramanian (1999: 70) notes how populist clientelism is attuned to the interests of emergent groups and effective at attracting their support. If it blunted the intolerance of early Dravidianism, however, it also blunted the impact of emergent groups and restricted the emergence of alternative agendas (Subramanian 1999: 72-3).

Throughout this paper we have seen how the VCK operates within this political sphere and both critiques and replicates mainstream politics. It is evident that the Liberation Panthers operate within a sphere of power, and that some of their challenges to the status quo actually reinforce it. Whilst they offer a critique of social norms and relationships, they are enmeshed within these very social forms and shaped by them. They are constrained by the wider political culture and conceptions of power and status (Mosse 2007). The expectations of cadre, media, opponents and potential constituents all help to define the possibilities on offer. As Racine and Racine (1998: 10) put it 'generally the model for emancipation is set (even if unwillingly) by the upper castes themselves. For many Dalits, emancipation is tantamount to an adoption of mainstream behaviour.' Ultimately, they note, Dalits seek a dissolution of 'dalitness'. But hegemonic politics leads down the path of Tamil nationalism and its emphasis on chastity and morality (implicitly based on caste norms) as well as attachment to heroic models of leadership prevent challenging groups from prefiguring more democratic organisations. Political recognition within a clientelist state, thus, comes at a price. Barnett (1976) notes how the DMK's 
political project entailed the creation of new ways of doing politics that ossified social structures and set the template for political performance in the state (Subramanian 1999, Bate 2009). The Tamilisation of Dalit movements and parties is always more than a mere discursive device, since such packaging has implications for how protest politics is conducted, experienced and interpreted.

Identities and politics-be they personal or institutional-are malleable but are also forged within particular socio-historical contexts and discursive forms that become naturalised. This paper suggests that political parties in Tamil Nadu display significant path-dependent behaviour. Path dependence, as Mahoney (2000: 507) explains, refers to 'institutional patterns or event chains that have deterministic properties'. Indeed, political trajectories in Tamil Nadu display an 'inherent sequentiality' (Mahoney 2000: 509) that may be traced back to the political template established by the non-Brahmin and Dravidian movements. In order to comprehend Tamil Dalit movements, we must appreciate the political and institutional culture within which they are embedded. Yet, it would be mistaken to see them as determined by this environment as some pathdependence theories would imply. Social structures such as caste may give the appearance of stability, but they are constantly subject to reinforcement, modification or alteration. Social actors, as Pandian (1992: 144-5) shows, may express dissent even as they reproduce social norms. Tamil politics, as he notes, is a 'contested terrain'. The VCK has been amongst the foremost challengers in recent years and has articulated a sustained critique of Dravidian rule, caste society and Hindu nationalism. Party rhetoric and analysis demonstrate its capacity to invert accepted wisdom and question taken-forgranted ways of doing things. All too often, however, its actions has belied these assertions and conformed to hegemonic forms.

By mobilising on the basis of caste, allying with alternate Dravidian parties, organising according to kingly models and valorising honour and caste pride, the VCK has been derided for selling out, becoming corrupt and betraying its ideals. On the eve of the 1999 election, Thirumavalavan launched a coruscating attack in which he 'unmasked' the Dravidian parties:

The DMK's alliance with the BJP has removed the mask of protecting Muslims. Now Karunanidhi stands revealed as a typical caste Hindu-not a Tamil, not a humanist, not anti-Brahmin or Brahminism, not a defender of Islam- a typical, pucca [proper] caste Hindu. ${ }^{30}$

By these measures, the VCK's mask has also slipped. Replicating dominant values and structures may be a pragmatic reconciliation with the political status quo-'not a change in principle, but a change in the rigidity of practice ${ }^{31}$-but it reinforces power asymmetries and forecloses more radical options. Tilly's (1998:11) work on enduring inequalities suggests that radical groups may be incorporated on adverse or uneven terms such that their 'emulation and adaptation [of existing modes of action] lock ... categorical distinctions into place, making them habitual and sometimes even essential to exploiters and exploited alike.' Following Gundimeda's (2009: 57) statement on Andhra Pradesh, one thus gets the impression that the institutionalisation of Dalit movements misses its goal if it merely ends up running 'parallel caste-based politics'. 


\section{Conclusion}

55 up the secession battle that will ensue once either Karunanidhi or Jayalalitha steps down as a critical opportunity for change, but it is an indictment of Tamil Dalit politics if they must await developments elsewhere. Entering political competition has amplified the voice of the Panthers, afforded them exposure in the media (both in interviews and Ravikumar's magazine articles), averted the accusations of extremism and expanded the terrain of Tamil politics. Institutionalisation, however, threatens to blunt the politics of the movement. If the public statements of the VCK are increasingly focused on Sri Lanka and the former extremists are now seen as puppets, then in what sense can political recognition be regarded as a 'success', in Gamson's terms, for the movement? 'It does not matter if it is taking time', Thirumavalavan insisted taking the long-term view, 'we must bear the inconveniences and afflictions that arise and slowly, slowly strengthen the movement'. ${ }^{32}$ In the meantime, their actions can serve to reinforce hegemonic politics: gone flocking round Jayalalitha. They are selling their people. There can be exploitation by movements against exploitation too. ${ }^{33}$

pace of change does not quicken, the accusations of disaffected cadre and rival leaders will increase. Path-dependent behaviour may throw up its own contingencies, of course, and 2009 witnessed Thirumavalavan becoming the first MP to be elected from an autonomous Dalit party in Tamilnadu. As Jaoul (2007) notes for Uttar Pradesh, however, Dalit politics has an impact in the social as well as political spheres. Becoming a party has enabled the VCK to invest more in cultural strategies, publications, conferences and other forms of consciousness-raising, such as the documentary and history films of Paari Chezhian. ${ }^{34}$

Enthusiastic party cadres point to a diminution of caste violence, though the more critical ones suggest that some of this is down to the VCK remaining silent about cases that it would have highlighted in the past. ${ }^{35}$ The billboards condemning atrocities and caste fanatics in the late 1990s and early 2000s have given way to glossy film style posters and murals of the VCK leader. The change in emphasis is perhaps best captured by wall paintings hailing Thirumavlavar (an honorific suffix to Thirumavalavan's name) as I could observe during a 2010 fieldwork. The axis of Dalit politics in the state appears to have shifted (in public at least) away from conflict with upper castes or Dravidian parties towards political recognition and consolidation. In other fields, the VCK has moved to recognise local commitment and the importance of women's support in the elevation of Pandiyammal ${ }^{36}$ to the city convenor in Madurai for instance. Given that the party has always drawn on a large reserve army of women activists (Gorringe 2005) such recognition is both welcome and overdue. This step offers some hope that the resources and security afforded by Thirumavalavan's election as MP could be harnessed to carve out new democratic spaces (Gundimeda 2009), that work towards the 'continuous realization of democracy as a concrete set of practices, instead of valorising it as an abstract ideal' (Pandian 2008: 7). The zeal with which the CPI(M) and the Tamil Nadu Untouchability Eradication Front have taken up issues of caste discrimination suggest that the political integration of the VCK has, perhaps, served to bring caste concerns to the fore. The continued marginalisation of Dalit actors, however, was painfully illustrated 
in September 2011 when the mishandling of a rally in honour of Dalit hero Immanuel Sekharan led to confrontation in which seven Dalits were shot dead by police in Paramakudi (Navayan 2011).

In sum, though, whilst Gamson (1990) and others view political engagement by social movements as indicative of 'success', the example of the VCK testifies to the uncertain benefits and tangible costs of political engagement. Gamson's typology of movement outcomes suggests that only those groups that fail to gain recognition are 'pre-empted' or 'collapse', the discussion above suggests that even full recognition of a movement can be read as failure. This reminds us that citizenship is a process. As Mosse (2007: 28) argues 'the broader point is that, in the shift from clientelism to citizenship, the terms of citizenship are often given in advance in ways that may not serve the needs of the poorest; citizenship has its exclusionary dimension.' Expanding the boundaries of citizenship will require more than just electoral contestation. Failing this, ever more people will concur with Lakshmanan's analysis ${ }^{37}$ that: 'The VCK are finished as a Dalit movement; they are just another party now'. ${ }^{38}$

\section{BIBLIOGRAPHY}

Anbuselvam (2002) 'Interview with Thirumavalavan', Thamukku: Newsletter of Dalit Resource Centre, 4(13), pp. 1-2.

Arun, Joe (2007) Constructing Dalit Identity, Jaipur: Rawat Publications.

Barnett, Marguerite R. (1976) The Politics of Cultural Nationalism in South India, Princeton: Princeton University Press.

Bate, Bernard (2009) Tamil Oratory and the Dravidian Aesthetic: Democratic Practice in South India, New York: Columbia University Press.

Chandhoke, Neera (1999) 'Courtailing (sic.) Ethnic Conflict', The Hindu, 7 March.

Chandra, Kanchan (2004) Why Ethnic Parties Succeed, Cambridge: Cambridge University Press.

Charsley, Simon (1996) “Untouchable'. What is in a Name?', Journal of the Royal Anthropological Institute, 2(1), pp. 1-23.

Chatterjee, Partha (1993) The Nation \& its Fragments, Princeton: Princeton University Press.

Chatterjee, Partha (2004) The Politics of the Governed, New Delhi: Permanent Black.

Coy, Patrick; Hedeen, Tim (2005) 'A Stage Model of Social Movement Co-optation: Community Mediation in the United States', The Sociological Quarterly, 46(3), pp. 405-435.

Deliege, Robert (1992) 'Replication \& Consensus: Untouchability, Caste \& Ideology in India', Man, 27 (1), pp.155-173.

Della Porta, Donatella; Diani, Mario (1999) Social Movements: An Introduction, Oxford: Blackwell. De Wit, Joop (1996) Poverty, Policy \& Politics in Madras Slums, London: Sage.

Economic and Political Weekly. 2010. 'Perfecting Patronage', 45(50). 
Gamson, William A. (1990) The Strategy of Social Protest, Belmont, CA: Wadsworth Publishing. George, Glynis (2002) 'Four makes society': Women's organisation, Dravidian nationalism and women's interpretation of caste, gender and change in South India', Contributions to Indian Sociology, 36(3), pp. 495-524.

Gorringe, Hugo (2005) Untouchable Citizens, Delhi: Sage.

Gorringe, Hugo (2007) 'Taming the Dalit Panthers? Dalit Politics in Tamiln Nadu', Journal of South Asian Development, 2(1), pp. 51-73.

Gorringe, Hugo (2010) 'Resounding Rhetoric, Retreating Rebels: The use and Impact of Militant Speeches in Tamil Dalit Movements,' Contemporary South Asia, 18 (3), pp. 281-292.

Goswami, Manu (2004) Producing India, Chicago: University of Chicago Press.

Gundimeda, Sambaiah (2009) 'Dalits, Praja Rajyam Party and Caste Politics in Andhra Pradesh', Economic and Political Weekly, XLIV (21), pp. 50-58.

Harriss, John (2002) 'Whatever Happened to Cultural Nationalism in Tamil Nadu?' Commonwealth \& Comparative Politics, 40(3), pp. 97-117.

Harriss, John (2006) Power Matters, Delhi: Oxford University Press.

The Hindu. 2006. 'DPI Cadres upset over Thirumavalavan's move', 2 April. URL: http://

www.hindu.com/2006/04/02/stories/2006040209770300.htm

The Hindu. 2009a. 'VCK Activist jumps down from Tower', 2 February. URL: http://

www.hindu.com/2009/02/02/stories/2009020259360400.htm

The Hindu. 2009b. 'Youth ends life in protest against killing of Tamils in Sri Lanka', The Hindu, 31 January. URL: http://www.hindu.com/2009/01/30/stories/2009013061230600.htm Irschick, Eugene (1994) Dialogue and History, Berkeley: University of California Press.

Jaffrelot, Christophe (2003) India's Silent Revolution, London: Hurst.

Jaoul, Nicolas (2007) 'Political and 'non political' means in the Dalit movement', in Sudha Pai (ed.), Political Process in Uttar Pradesh: Identity, Economic Reform and Governance, New Delhi: Pearsons, pp. 142-168.

Jenkins, Craig (1995) 'Social Movements, Political Representation \& the State’, in Craig Jenkins \& Bert Klandermans (eds.), The Politics of Social Protest, Berkeley: University of California Press, pp. 14-35.

Jenkins, Rob (1999) Democratic Politics \& Economic Reform in India. Cambridge: Cambridge University Press.

Karanth, Gopal (2004) 'Replication or dissent? Culture and institutions among 'Untouchable' Scheduled Castes in Karnataka’, Contributions to Indian Sociology, 38(1\&2), pp. 137-63.

Kolappan, B. (2008) 'Can’t work with Thirumavalavan', The Hindu, 13 August. URL: http:// www.hinduonnet.com/thehindu/thscrip/print.pl?file=2008081359971000.htm\&date=2008/08/13/ \&prd=th\&

McCarthy, John; Zald, Mayer (1987) 'The Trend of Social Movements in America: Professionalisation and Resource Mobilization', in Mayer Zald \& John McCarthy (eds.), Social Movements in an Organizational Society. New Brunswick: Transaction, pp. 337-91.

Mahoney, James (2000) 'Path Dependence in Historical Sociology', Theory \& Society, 29(4), pp. 507-48. 
Mines, Mattison (1994) Public Faces, Private Voices, Berkeley: University of California Press.

Moffatt, Michael (1979) An Untouchable Community in South India, Princeton: Princeton University Press.

Mosse, David (1994) 'Idioms of Subordination and Styles of Protest among Christian and Hindu Harijan Castes in Tamil Nadu', Contributions to Indian Sociology, 27(1), pp. 67-104.

Mosse, David (2007) ‘Power and the Durability of Poverty', Chronic Poverty Research Centre Working Papers, Nb. 107.

Navayan, Karthik (2011) 'What actually happened in Paramakudi and how it happened', Round Table India Blog. URL: http://roundtableindia.co.in/index.php?

option=com_content\&view=article\&id=3784:-what-actually-happened-in-paramakudi-and-howit-happened\&catid=119:feature \&Itemid $=132$

Offe, Claus (1990) 'Reflections on the Institutional Self-Transformation of Movement Politics', in Russell Dalton \& Manfred Kuechler (eds.), Challenging the Political Order, Cambridge: Polity, pp. 232-50.

Pai, Sudha (2002) Dalit Assertion and the Unfinished Democratic Revolution, Delhi: Sage.

Pandian, M. S. S. (1992) The Image Trap, New Delhi: Sage.

Pandian, M. S. S. (2000) ‘Dalit Assertion in Tamil Nadu: An Explanatory note', Journal of Indian School of Political Economy, XII (3 \& 4), pp. 501-17.

Pandian, M. S. S. (2006) 'Tamil Nadu: New Times Ahead', Economic and Political Weekly, 41(22), pp. 2181-2183.

Pandian, M. S. S. (2008) 'Caste and Democracy: Three Paradoxes', Conference Proceedings of The Dalit Studies Conference, 3-5 December, Centre for the Advanced Study of India, Philadelphia: University of Pennsylvania.

Price, Pamela (1989) 'Kingly Models in Indian Political Behaviour', Asian Survey, 29(6), pp. 559-572.

Racine, Jean-Luc; Racine, Josiane (1998) 'Dalit Identities and the Dialectics of Oppression and Emancipation', Comparative Studies of South Asia, Africa and the Middle East, 18 (1), pp. 5-20.

Rajadurai, S.; Geetha, V. (2002) 'A Reply to John Harriss', Commonwealth and Comparative Politics, 40(3), pp. 118-124.

Ravikumar (2002) 'Caste of the Tiger: Eelam and the Dalit Question', Himal, August (Translated by R. Azhagarasan). Available at URL: http://www.ambedkar.org/News/News080802.htm (Accessed January 2012)

Ravikumar (2006) 'Re-Reading Periyar', Seminar, 558, February. URL: http://www.indiaseminar.com/semsearch.htm

Ravikumar (2009) Venomous Touch: Notes on Caste, Culture \& Politics, Kolkata: Samya (Translated by R. Azhagarasan).

Roberts, Nathaniel (2010) 'Language, Violence, and the State: Writing Tamil Dalits', South Asia Multidisciplinary Academic Journal. Online since 31 January 2010. URL: http://samaj.revues.org/ index2952.html

Scott, James (1985) Weapons of the Weak, Berkeley: University of California Press.

Sebastian, M. (1994) Liberating the Caged Dalit Panther, Madras: Emerald Publishers. 
Sridharan, Eswaran (2001) 'Reforming Political Finance', Seminar, 506. URL:

http://www.india-seminar.com/2001/506/506\%20e.\%20sridharan.htm

Subramanian, Narendra (1999) Ethnicity \& Populist Mobilization, Delhi: Oxford University Press.

Subramanian, Narendra (2002) 'Identity Politics \& Social Pluralism: Political Sociology and

Political Change in Tamil Nadu', Commonwealth \& Comparative Politics, 40(3), pp. 125-39.

Subramanian, Narendra (2005) 'Political Formation of Cultures: The South Asian Experience',

Economic and Political Weekly, 40(35), pp. 3821-27.

Subramanian, T. (2001) 'The Caste of Characters', Frontline, 18(4), pp. 46-8.

Tarrow, Sidney (1998) Power in Movement, Cambridge: Cambridge University Press.

Thirumavalavan, R. (2003) Talisman: Extreme Emotions of Dalit Liberation (compiled and

translated by M. Kandasamy), Kolkata: Samya.

Tilly, Charles (1998) Durable Inequality, Berkeley: University of California Press.

Venkatsubramanian, A. K. (2006) 'The Political Economy of the Public Distribution

System in Tamil Nadu', in Vikram Chand (ed.), Reinventing Public Service Delivery in India, New

Delhi: Sage, pp. 266-93.

Viswanathan, S. (2004) 'A History of Agitational Politics', Frontline, 2(8), URL:

http://www.hinduonnet.com/fline/fl2108/stories/20040423007201600.htm

Walby, Sylvia (2003) 'The Myth of the Nation-State', Sociology, 37(1), pp. 531-48.

Washbrook, David (1976) The Emergence of Provincial Politics: The Madras Presidency 1870-1920, Cambridge: Cambridge University Press.

Wyatt, Andrew (2002) 'New Alignments in South Indian Politics', Asian Survey, 42(5), pp. 733-53.

Wyatt, Andrew (2010) Party System Change in South India: Political Entrepreneurs, Patterns and Processes, London: Routledge.

\section{NOTES}

1. Thirumavalavan, interview by author, Chennai, November 1999. Thirumavalavan is the leader of the Viduthalai Ciruthaigal Katchi (VCK)-the largest Dalit Party in Tamil Nadu.

2. 'Tada' Periyasami, interview by author, Chennai, November 1999. At the time of the interview 'Tada' Periyasami was Assistant General Secretary of the VCK, though he left the Party in 2002 to form his own group.

3. See Charsley (1996) on the naming of Untouchables. Scheduled Caste (SC) is the constitutional epithet for ex-Untouchables entitled to positive discrimination (reservations). It does not, thus, refer to ex-Untouchables who have converted to Christianity even though they are included in the Dalit category. Gandhi used Harijan, meaning 'children of God', to reject the perceived impurity of Untouchables, but the name is seen as insulting because it evokes the offspring of cross-caste marriages or Devadasis (temple prostitutes).

4. Muthukumar (pseudonym), interview by author, Edinburgh, August 2008. This paper draws on fieldnotes and interview data from research on Tamil Dalit movements in 1998-99, and short follow-ups in 2002 and 2010. Where appropriate, names have been anonymised.

5. T. Edwin (pseudonym), telephone interview by author, Madurai, September 2008.

6. I thank Sudipta Kaviraj for helping to clarify my argument here. 
7. On the non-Brahmin movement see Washbrook (1976), Pandian (1995), Subramanian (1999).

8. 'Anna' refers to Annadurai, the founding father of the DMK. The AIADMK claims to be closer to his ideals.

9. P. Subramaniam (pseudonym), interview by author, Cuddalore, April 1999.

10. See Subramanian (2002: 129) on reservations in Tamil Nadu. Though the extension of reservations to Other Backwards Classes by the Dravidian parties initially benefited dominant castes, they subsequently differentiated between Backward and Most Backward Castes and set aside a quota for women. On the scale and success of the public distribution system in the state, see Venkatsubramanian (2006).

11. I am grateful to one of SAMAJ referees for emphasizing this point.

12. The emergence of film-star Vijayakanth as a political contender in 2006 was significant for his attempt to challenge the Dravidian parties on their own terms and reach beyond caste constituencies by virtue of his image. On this, see Pandian (2006).

13. Muthukumar (pseudonym), interview by author, Edinburgh, August 2008.

14. R. Thirumavalavan, speech recorded and translated by author, Melakottai, 16 June 1999.

15. SCs comprise $18 \%$ of the Tamil population. Of the 72 recognised Scheduled Castes, there are three main groups: Pallars, Paraiyar and Chakkiliyars. Although the most numerous category is 'Adi-Dravidar' and there are entries for Chakkiliyars, Arundhadiars, and Madaris, such categories are contested and political. Adi-Dravidar means 'original Dravidian' and was adopted by Untouchable groups in the late $19^{\text {th }}$ and early $20^{\text {th }}$ centuries (primarily by Paraiyar castes) to improve their status. Chakkiliyar, Arundhadiar and Madari are used interchangeably on the ground, as are Pallar and Devendra Kula Vellallar. Accepting common usage, there are approximately 4.6 million Paraiyars, 1.3 million Pallars, and 1.25 million Chakkiliyars (Sebastian 1994: Chapter 2).

16. Kannadasan (pseudonym), interview by author, Madurai, July 1999. 'MGR' is a derogatory remark likening Thirumavalavan to the AIADMK icon.

17. R. Thirumavalavan, speech recorded and translated by author, Chennai, 1 December 1999.

18. For similar work on other parties, see Bate (2009).

19. Karthik (pseudonym), interview by author, Madurai, January 2010.

20. Anandan Paraiyar, interview by author, Melavalavu, November 1999.

21. 'Tada' Periyasami, interview by author, Chennai, November 1999.

22. P. Subramaniam (pseudonym), interview by author, Cuddalore, April 1999.

23. R. Manohar, interview by author, Bangalore, January 2010.

24. Jahavar, interview by author, Madurai, January 2010.

25. R. Thirumavalavan, interview by author, Chennai, November 1999.

26. Paari Chezhian, interview by author, Allanganallur, January 2010.

27. Kamaraj, interview by author, Vadipatti, March 1999.

28. For similar analysis of the BSP's political performance in Uttar Pradesh, see Jaoul (2007).

29. Paari Chezhian, interview by author, Allanganallur, January 2010.

30. R. Thirumavalavan, speech recorded and translated by author, Chennai, 1 December 1999.

31. R. Thirumavalavan, speech recorded and translated by author, Chennai, 1 December 1999.

32. R. Thirumavalavan, interview by author, Chennai, November 1999.

33. 'Dalit' Gnanasekharan, interview by author, Madurai, July 1999.

34. Who kindly provided me with his films on Parpapatti reserved-panchayat (council) and on Iyothidoss Pandithar, the pioneering Dalit reformer.

35. Paari Chezhian, interview by author, Allanganallur, January 2010.

36. See Gorringe (2005: Chapter 6) for more on this inspiring, female grass-roots leader.

37. Lakshmanan, interview by author, Chennai, January 2010.

38. Many thanks to Ram Rawat and Tanya Carey at the Centre for the Advanced Study of India, University of Pennsylvania where this article was first presented. I am grateful to Sudipta Kaviraj 
and Sam Gundimeda for comments on the conference paper. I am, though, thoroughly indebted to the two anonymous reviewers for SAMAJ whose valuable comments have helped to sharpen the aim and focus of the paper. The data here draws on ESRC funded doctoral work in 1998-9, and a small project funded by The Carnegie Trust for the Universities of Scotland in 2010.

\section{ABSTRACTS}

The Viduthalai Ciruthaigal Katchi (VCK, Liberation Panther Party) has successfully transformed from the largest Dalit movement in Tamil Nadu into a recognised political organisation. Social movement theorists like Gamson (1990) view political recognition and engagement as one of the main aims and successes of social mobilisation. Despite the obvious achievements of the VCK, however, activists and commentators express disappointment or disillusionment with its performance. The Panthers clearly reject the caste hierarchy, but they increasingly adopt hegemonic forms of politics which can undermine their aims. This paper, thus, engages with the questions of movement institutionalisation by tracing the political trajectory of the VCK and charting its resistance to and compliance with Dravidian hegemony. It argues that institutionalisation needs to be understood within particular socio-political contexts and notes how the hegemony of Dravidian politics partly explains the disjuncture between activist and political perceptions. It portrays how the dominant political parties have set the template for what it means to 'do' politics in Tamil Nadu which serves as both an opportunity and a constraint for potential challengers.

\section{INDEX}

Keywords: caste, Dalits, institutionalization, political participation, Tamil politics

\section{AUTHOR}

\section{HUGO GORRINGE}

Senior Lecturer in Sociology, University of Edinburgh 